\title{
1. Introduction to Counterterrorism and Investigative Detention
}

The use of physical detention as a tool to help enforce laws and social norms is as old as human civilization. ${ }^{1}$ Some form of detention has been utilized in the facilitation of an orderly society from the first moment that early humans began to organize and some recalcitrant or noncompliant member of the group needed to be compelled or coerced in some way - to be brought before authorities to take part in some judicial procedure, to be questioned, or to be punished. ${ }^{2}$ For instance, in the seventh century, the code of law set forth by Draco, the Athenian lawgiver, "permitted any citizen to arrest a homicide, who had illegally returned from exile, and personally bring him before the Court."3 Later examples include the biblical account of the Sanhedrin ordering the arrest of Jesus of Nazareth, so that he could be brought before Pontius Pilate to be tried for blasphemy. ${ }^{4}$ So long as there has been a range of forbidden activity and a desire for authorities to control it, the seizure and forcible direction of human bodies has been an element of governance and law enforcement.

It has always been clear that the exercise of detention-whether used to compel an act, facilitate eventual punishment, or as a punishment all its own - is an innately coercive practice. Writing in the eighteenth century, one commentator defined an arrest as "the restraint of a man's person, depriving him of his own will and liberty, and binding him to become obedient to the will of the law." ${ }^{\circ}$ And writing two centuries later, in language that still resonates

1 Moshe Berent, Greece: The Stateless Polis (11th-4th Centuries B.C.), in THE Early State, Its Alternatives and Analogues 367, 446 (2004).

2 Harold Nuttall Tomlins, A Digest of the Criminal Statute Law of England, Alphabetically and Analytically Arranged, Vol. 2, 722 (1819); Edward M. Peters, Prisons Before the Prison: The Ancient and Medieval World, in The Oxford History of the Prison: The Practice of Punishment in Western Society (1998); see also Henry Boswell, The Antiquities of England and Wales Displayed (1795); Mahesh Kumar Sharan, Court Procedure in Ancient India, ON THE BASIS OF DHARMaŚĀSTRA Literature (1978).

3 Anton-Hermann Chroust, Legal Profession in Ancient Athens, 29 Notre Dame L. REv. 339, 340 (1954).

4 Mark 14:53-65.

5 Robert Boyd, The Office, Powers, and Jurisdiction, of His Majesty's Justices of the Peace and Commissioners of Supply, Vol. 1, 73 (1787). 
with judicial force in the United States, US Supreme Court Justice Jackson stated, "Arrest itself is inherently coercive, and so is detention." Despite its necessity, this kind of coercive government authority has always struck a note of discord with liberal Western values. As Benjamin Wittes, a Senior Fellow in Governance Studies at the Brookings Institution, notes, "The Western world does not believe in detention. Even when Western nations need detention, they do not believe in it or want to acknowledge it, and so, over the years, they have developed elaborate systems for pretending they do not engage in it."7 It is, therefore, no wonder that legal regimes have paid careful attention to its regulation, and that criticisms and concerns regarding its proper use continue to be raised.

Many degrees of restraint qualify as detention - from brief stops by police asking questions on the street or in the subway, to longer periods of detention employing more severe constraints. Likewise, under domestic and international law, there are many different forms of detention, each with its own undergirding philosophy or constituent theory that justifies and guides its use. For instance, penal detention, or imprisonment after trial, is "imposed to punish, to deter, and to rehabilitate the convict." by governments, however, are not punitive in nature. As an example, "preventive detention," as its name implies, "entails the incarceration of a person who has not been convicted of a criminal offense, based on his dangerousness, in order to prevent him from causing public harm." Similarly, in times of war or armed conflict, battlefield detention exists under the law of armed conflict "to prevent captured individuals from returning to the field of battle and taking up arms once again." 10

6 Ashcraft v. State of Tenn., 322 U.S. 143, 161, 64 S. Ct. 921, 930, 88 L. Ed. 1192 (1944); see also Grischa Merkel, Detention Before Trial and Civil Detention of Dangerous Individuals, in The Oxford Handbook of Criminal Process (2019) 499 ("Because it interferes with the right to freedom, detention is the most severe pretrial measure").

7 Benjamin Wittes, Detention and Denial: The Case for Candor After Guantanamo 3 (2011).

8 Anderson v. Nosser, 438 F.2d 183, 190 (5th Cir. 1971).

9 Rinat Kitai-Sangero, The Limits of Preventive Detention, 40 McGeorge L. Rev. 903, 904 (2009).

${ }_{10}$ Al-Marri v. Hanft, 378 F. Supp. 2d 673, 680 (D.S.C. 2005), citing Yasmin Naqvi, Doubtful Prisoner-of-War Status, 84 InT'L Rev. Red Cross 571, 572 (2002) (“captivity in war is 'neither revenge, nor punishment, but solely protective custody, the only purpose of which is to prevent the prisoners of war from further participation in the war" (quoting decision of Nuremberg Military Tribunal, reprinted in 41 AM. J. INT'L L. 172, 229 (1947)). See also H. Martin Jayne, Preventive Detention-Restricting the Freedom to Harm, 2008 J. Inst. Just. InT'L Stud. 166, 181 (2008). 
The form of detention that is the subject of this book is "investigative detention" - a phrase that can be subject to various meanings. For instance, in the United States, it is common to refer to a brief stop of a suspect that falls short of full arrest as an investigative stop or investigative detention. In some cases, the phrase is conflated with preventive detention or detention without trial. ${ }^{11}$ Investigative detention, as the phrase is used in this book, however, specifically refers to the pre-charge detention of a suspect for the purpose of obtaining evidence for use at a subsequent criminal prosecution. This necessarily implies: (a) a certain lack of evidence at the outset of detention; (b) an investigation of some sort during the period of detention designed to obtain usable evidence; (c) the lack of formal charges against the detained person during the relevant period of detention; and (d) the eventual release of the suspect or, alternatively, the subjection of the suspect to a criminal proceeding that can determine his or her guilt or innocence.

Investigative detention, as defined in this book, is not an extraordinary mechanism but an ordinary aspect of a country's organic criminal justice regime. As the world witnessed in the immediate aftermath of $9 / 11$, perceived strictures in domestic criminal law can sometimes drive governments to seek extrajudicial or alternative means of dealing with terrorists, such as military detention, military tribunals, and preventive detention regimes. ${ }^{12}$ Professor Doug Cassel notes, "In many cases, the obstacles to prosecution may lead States to look for other, more practical ways to remove suspected terrorists from the streets." 13 As this book highlights, however, extrajudicial mechanisms such as special courts with different rules tend to be less durable and less successful as a long-term counterterrorism approach. Thus, detention capabilities within the ordinary criminal justice processes are extremely important. As one UN report has noted, "[a] forward-looking, preventive criminal justice strategy against terrorist violence requires a comprehensive system of substantive offences, investigative powers and techniques, evidentiary rules, and inter-State cooperation mechanisms." ${ }^{14}$ Investigative detention has been expressly identified by

11 See, e.g., Kam C. Wong, Legalism and Constitutionalism in the People's Republic of China, 1(2) Int'L Journal of Crim. Justice Sciences 1 (2006).

12 Douglass Cassel, Pretrial and Preventive Detention of Suspected Terrorists: Options and Constraints under International Law, 98 J. CRIM. L. \& CRIMINOLOGY 811, 830 (2007-2008).

13 Id.

14 See United Nations Office on Drugs and Crime (Terrorism Prevention Branch), Preventing Terrorist Acts: A Criminal Justice Strategy Integrating Rule of Law Standards in Implementation of United Nations Anti-Terrorism Instruments (2006) (hereinafter "Preventing Terrorist Acts"), http://www.unodc.org/pdf/terrorism/TATs/ en/3IRoLen.pdf. 
some experts as an element of such a system. ${ }^{15}$ It is a means of empowering law enforcement to proactively seize an individual and hold that person for the purposes of disrupting criminal activity, conducting an interrogation, obtaining evidence, and ensuring the integrity of an ongoing investigation. ${ }^{16}$

Legal literature over the past decade has expanded its focus beyond issues related to military and preventive detention in connection with terrorist suspects, and now includes more fulsome discussions of investigative detention for the purpose of criminal prosecution. ${ }^{17}$ Even so, the international and comparative legal evolutions attendant to this topic have remained largely unexplored. This book, therefore, seeks to shed greater light on investigative detention within the domestic criminal process - illuminating its characteristics, its capabilities, and its limitations. In addition, it examines ways in which the development of international law vis-à-vis investigative detention, coupled with governmental responses to terrorism, has shaped domestic legal regimes in ways that challenge our views of paradigmatic comparative law categories. Thus the book is both an inquiry into how different governments with different legal traditions detain terrorists for investigative purposes, and an exploration of how the catalyzing forces of international law and national security imperatives have combined to reshape domestic legal regimes so that, at least in the discrete area of investigative detention, ostensibly divergent legal models take on similar shapes, while supposedly similar systems begin to deviate. This exploration has a clear operational value in explicating the limits and authorities of international partners in carrying out certain national security functions, but should also be of intellectual interest to comparative legal theorists as it permits a reevaluation of received ideas and accepted comparative legal frameworks.

\section{A THE PROBLEM AND THE CONFLICT}

The problem and the conflict surrounding investigative detention can be analyzed using two images that illustrate both sides of an extremely complex issue: (a) the image of the potential devastation and bloodshed that counterterrorism laws and policies seek to prevent; and (b) the image of government abuse of its authority in a way that violates human rights and/or other foundational tenets of liberal democracy.

15 See Jeremy Shapiro, Detention of Terrorism Suspects in Britain and FranCE, Brookings Institution, July 15, 2008.

16 Id.

17 See, e.g., Benjamin Wittes, LaW and the Long War (2008); Stephanie Cooper Blum, The Necessary Evil of Preventive Detention in the War on TERROR (2008). 


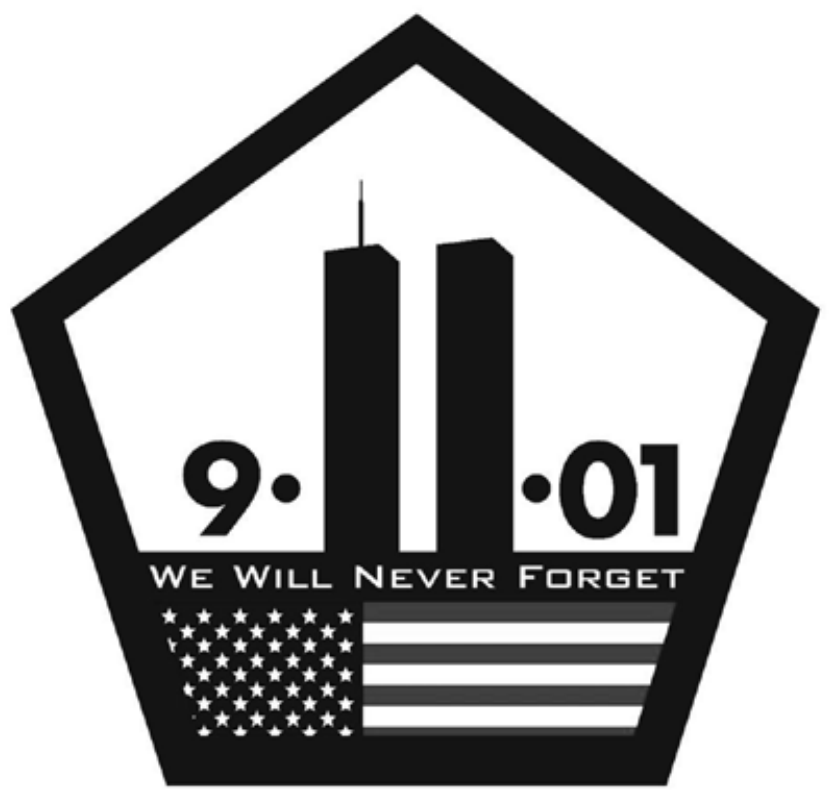

Source: iStock.

Figure 1.1 "We will never forget"

The image of the aftermath of the September 11 attacks had a profound impact on the collective American psyche. The memories and images of the horror of that day, and the security-focused reaction captured in this iconic graphic (Figure 1.1), indelibly colored the lens through which the US population and policymakers viewed - and continue to view - the world. It similarly impacted the way populations and policymakers from other countries viewed national security. These images were still fresh when, on January 9, 2003, a US naval officer named Vice Admiral Lowell E. Jacoby completed a declaration that would be submitted as part of the record in the matter of Jose Padilla $v$. George W. Bush, et al. ${ }^{18}$ The United States, still reeling from the September 11

18 See Declaration by Vice Admiral Lowell E. Jacoby, United States Navy, January 9, 2003 (hereinafter "Jacoby Declaration"), p. 1, www.pegc.us/archive/Padilla_vs _Rumsfeld/Jacoby_declaration_20030109.pdf. 
attacks, was engaged in an aggressive new counterterrorism strategy. Federal agents had captured and detained Jose Padilla — a US citizen - because he was suspected of engaging in terrorist activity. Padilla was, thereafter, labeled an enemy combatant, handed over to the Department of Defense, and held incommunicado by the military without access to an attorney or anyone else except those interrogating him.

As one might expect, Padilla filed for a writ of habeas corpus to challenge his detention. The US government, therefore, needed someone to explain this strikingly extreme situation to a federal court - to explain why it was necessary to hold someone in detention for a prolonged period without granting that person access to an attorney or outside assistance. For that, they turned to Vice Admiral Jacoby, who was the Director of the Defense Intelligence Agency. ${ }^{19}$

In his declaration, Vice Admiral Jacoby noted that interrogation- "the art of questioning and examining a source to obtain the maximum amount of usable, reliable information in the least amount of time to meet intelligence requirements"-is a fundamental tool for gathering of intelligence. ${ }^{20}$ Prolonged incommunicado detention, the Vice Admiral noted, was critical to "minimize external influences on the interrogation process" and, thus, maximize the quality and quantity of intelligence produced. ${ }^{21}$ He concluded by declaring:

In summary, the War on Terrorism cannot be won without timely, reliable, and abundant intelligence. That intelligence cannot be obtained without robust interrogation efforts. Impairment of the interrogation tool-especially with respect to enemy combatants associated with al Qaida-would undermine our Nation's intelligence gathering efforts, thus jeopardizing the national security of the United States. ${ }^{22}$

Four years after that memorandum was completed, in a 2007 op ed in the Wall Street Journal, Michael B. Mukasey, then-US Attorney General, called out for a statute that would give US law enforcement investigative detention powers similar to those of their European counterparts, stating that "[the US Material Witness Statute] was used frequently after $9 / 11$, when the government tried to investigate numerous leads and people to determine whether follow-on attacks were planned - but found itself without a statute that authorized investigative detention on reasonable suspicion, of the sort available to authorities in Britain and France, among other countries." ${ }^{23}$

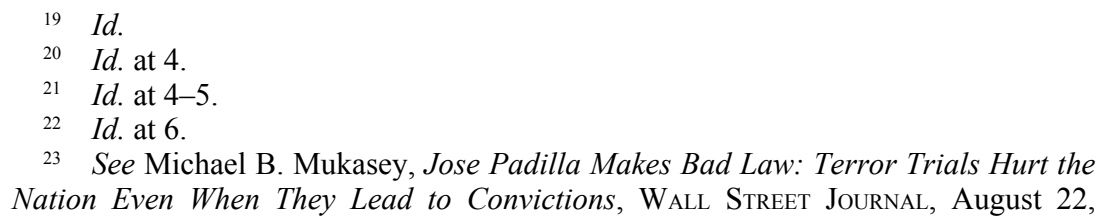


The challenges associated with the detention of terrorist suspects for criminal matters have remained significant and complex in the years since the Padilla case and the former Attorney General's commentary-and both the operational and legal approaches adopted by US authorities have evolved. For instance, commentators have noted the emergence of the operational practice of "detaining terrorism suspects on naval ships for a temporary period of [law of armed conflict] detention prior to bringing them to the United States for federal prosecution." ${ }^{24}$ As discussed in this book, examples of this practice were seen in 2011, when "U.S. forces captured Somali terrorist suspect Ahmed Abdulkadir Warsame off the coast of Yemen and held him for more than two months aboard a naval ship in the Gulf of Aden before flying him to the United States for prosecution in New York." ${ }^{25}$ Other examples include the 2013 capture of Abu Anas al-Libi by US special operations forces in Libya and al-Libi's subsequent detention aboard a navy ship in international waters eight days prior to his transfer to the United States for prosecution. ${ }^{26}$ And even more recently, subjects implicated for their roles in the 2012 Benghazi attacks were similarly captured and detained on naval vessels in international waters, where they were subject to interrogation before being transferred to civilian law enforcement authorities. ${ }^{27}$ An evolving threat landscape, including legal and operational challenges associated with terrorists operating in ungoverned spaces, yielded new counterterrorism approaches and shaped the way in which terrorists were apprehended and detained for investigative purposes.

Viewed through the lens of this first image, such detention authorities do not seem viscerally objectionable as we are reminded of the destruction that counterterrorism laws and policies seek to avert. Other images, however, remind us of considerations that should always inform national security decisions.

\section{The Image of Human Rights}

Interrogation I (Figure 1.2) is a painting by Friedl Dicker-Brandeis. A politically active Jewish artist, Dicker-Brandeis was arrested and interrogated by Austrian government authorities during the rightist putsch carried out by Austrian Nazis in Vienna in $1934 .{ }^{28}$ Interrogation I depicts her interrogation

24 Jonathan Hafetz, Abu Khattalah and the Evolution of Ship-Based Detention, JusT SECURITY (June 28, 2014) https://www.justsecurity.org/12395/abu-khattalah-evolution -ship-based-detention/.

${ }_{25}$ Id.

$26 \quad I d$.

27 Id.

28 Elena Makarova, Friedl Dicker-Brandeis, 1898-1944, EnCyClopedia of Jewish WoMEN, https://jwa.org/encyclopedia/article/dicker-brandeis-friedl ("Her second crea- 


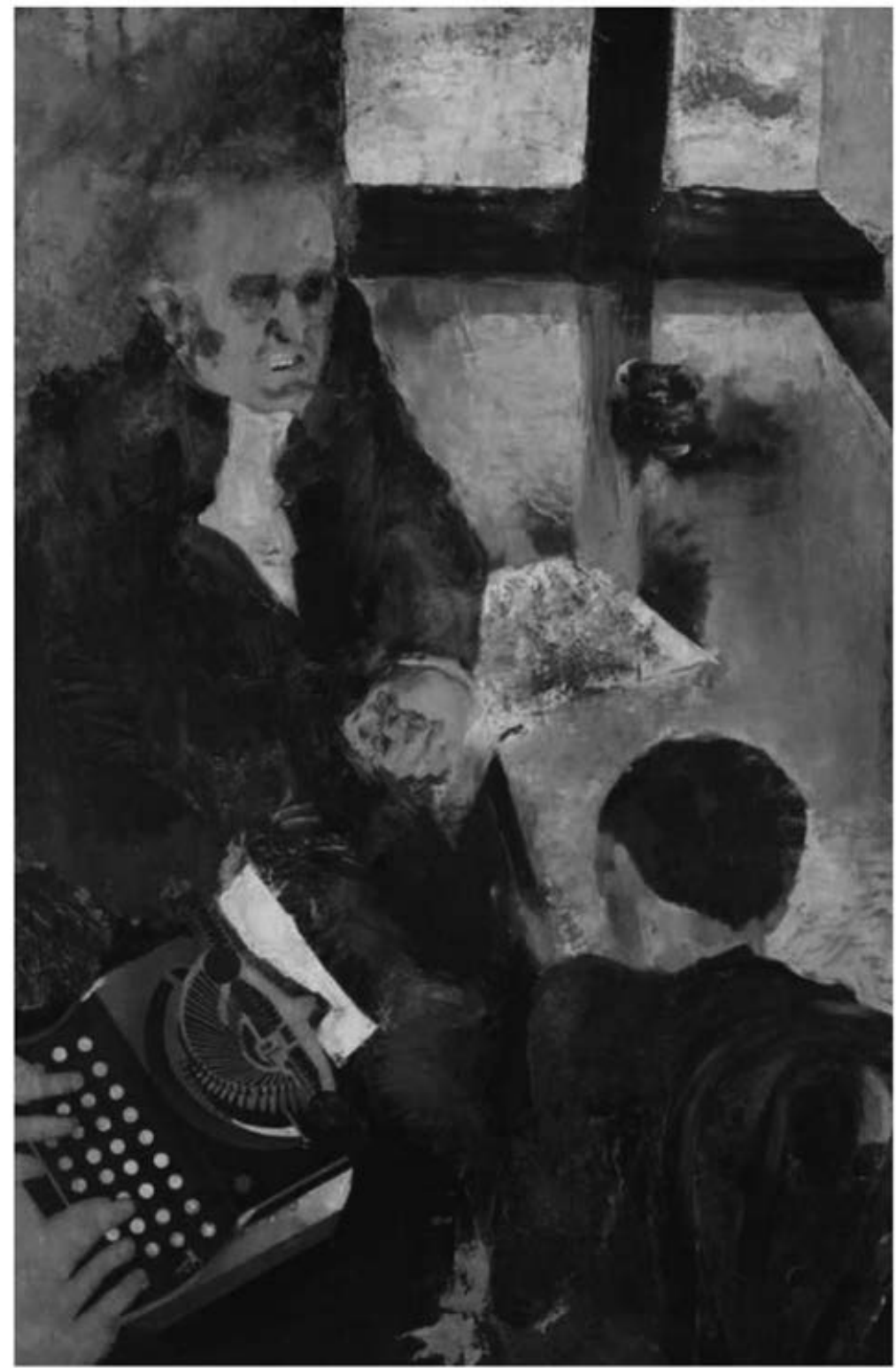

Source: Jewish Museum, Prague.

Figure 1.2 Interrogation I, Friedl Dicker-Brandeis 
during that period. In the painting, which is said to be her only self-portrait, her face is turned away from the viewer. She is slumped forward, powerless and withering in the face of her menacing interrogator. Interrogation I reminds the viewer of the vulnerability of the detained person and the potential for injustice - a potential that was, sadly, realized for Dicker-Brandeis. The painter would be released after her interrogation and imprisonment, but the Nazi menace followed her. As historian Elena Makarova notes, "[a]fter a short imprisonment, she moved to Prague, which was at that time a stronghold of democracy in Nazi-infested Central Europe, only to be later murdered in a gas chamber on Oct. 9, 1944."29 This image, and certainly the biography of its creator, prompts a painful reminder that government powers are not always used for righteous objectives. Governmental authority can be abused and therefore requires a cordon of legal restraint (sometimes called "the rule of law") and appropriate oversight. While images of authoritarian governments and Nazi oppression may seem far removed from the lives of many readers, there are, indeed, many places in the world where detention authorities remain a tool of oppression. According to Amnesty International, "[i]n many countries throughout the world, no proper process is followed and no safeguards are in place: such as lawyers present during interrogations; independent doctors on-hand to examine detainees; contact with families and ensuring confessions obtained by torture can never be used as evidence. ${ }^{\prime 30}$ Accordingly, the counterbalances found in domestic law and international human rights law must also be given equal consideration when formulating laws and policies that relate to the detention and questioning of persons suspected of criminal activity, including that range of activity related to terrorism. Though frequently motivated by images of security, we must not lose sight of images such as Interrogation I.

\section{B THE VALUE OF DETENTION}

Whether for use in the courtroom or on the battlefield abroad, detention and interrogation are central to the effort to combat terrorism. As Vice Admiral Jacoby notes, interrogation is important for military reasons, such as developing information needed to counter the "asymmetrical" threat posed by

tive period is characterized by a decisive shift toward painting. In her transitional work, The Interrogation, she mixes graphic elements such as typewriter letters on wood with oil painting. The Interrogation is her only self-portrait, but even here she turns her back on the observer, seeming to be keeping her distance even from herself').

$29 \quad I d$.

30 Amnesty International, Detention And Imprisonment, https://www.amnesty .org/en/what-we-do/detention/\#: :text=Under\%20international\%20human $\% 20$ rights $\% 20$ law,right $\% 20$ to $\% 20 \mathrm{a} \% 20$ fair $\% 20$ trial. 
terrorists. ${ }^{31}$ And, as the commentary of former Attorney General Mukasey demonstrates, such information is equally critical to civilian criminal institutions in their effort to ferret out terrorist operations domestically. In either case, it is obvious that, in order to accomplish such interrogation, one must first detain a person so that he or she can be interrogated; otherwise stated, if interrogation forms a critical part of the counterterrorism effort, detention is its necessary antecedent. ${ }^{32}$ Additionally, detention is a necessary antecedent for the collection of biometric data (fingerprints, facial patterns, DNA, voice cadence, etc.), which, in the modern counterterrorism context, is critical to safeguarding national security. As Russell Travers, former Acting Director of the National Center for Counterterrorism, maintains:

As we saw in the attacks in Paris and Brussels, the use of high-quality, fake national ID cards and passports will challenge any names-based system. To ensure operational relevance, we will need to strive for near real-time vetting such that the officer doing the screening can enter available biographic and biometric information and determine if there is any available data to suggest that the individual is a known or suspected terrorist. We will need to enhance our focus on collection, sharing, and using biometrics. With upwards of two million screening opportunities per day, this near real-time biographic/biometric screening will be a daunting task, but it will be required to keep pace with the threat. ${ }^{33}$

Detention, therefore, is important as a condition precedent for interrogation as well as for the collection of biometric information that enables authorities to identify terrorists, build holistic identities for terrorist suspects, effectively screen for terrorists at national borders, and so on. As explained in these pages, however, the detention of an individual in a liberal democracy is an exceptional measure and, therefore, cannot be undertaken without also incorporating important legal safeguards that exist to ensure due process, prevent abuse by government authorities, and generally protect against improper deprivations of liberty. The need to ensure the existence of an appropriate legal framework for investigative detention makes it as complicated as it is important. This complexity exists at some level whether the detention is on the battlefield (under the law of armed conflict) or in more ordinary circumstances (under

31 See Jacoby Declaration, supra note 18 , at 5.

32 Hugh Rawson \& Margaret Miner, eds., The Oxford Dictionary of American Quotations 595 (2006), citing Franklin D. Roosevelt, fireside radio talk, September 11, 1941 ("When you see a rattlesnake poised to strike, you do not wait until he has struck before you crush him").

33 Russell E. Travers, Deputy Dir., U.S. Nat'l Counterterrorism Ctr., Counterterrorism in a World of Competing Priorities, Remarks as Prepared for the World Counter Terror Cong., London (March 5, 2019). 
a country's domestic criminal law).$^{34}$ As the subsequent chapters of this book will emphasize, the evolution of the terrorist threat makes this latter category of detention even more consequential.

\section{COMPARATIVE LAW AND COMPARATIVE LEGAL PARADIGMS}

As this book will illuminate, while much of the counterterrorism fight continues in the form of battlefield engagements, the terrorist threat has never been isolated to the battlefield. Terrorists have always operated with equal facility in cities and towns, where police and civilian law enforcement authoritiesrather than soldiers - patrol the streets. As such, while military action on the battlefield will continue, governments must also formulate strategies in their criminal justice institutions for handling the problem of terrorists at home. ${ }^{35}$ Well-informed strategies must take into account the characteristics of those institutions, how they differ from country to country, and the important lessons learned from decades of counterterrorism experience across diverse jurisdictions. This book seeks to investigate that field of knowledge in order to better inform future counterterrorism strategies and, therefore, sits at the nexus of comparative law and national security. These two subjects are symbiotic. After all, "comparative law is an école de vérité which extends and enriches the supply of solutions and offers the scholar of critical capacity the opportunity of finding the 'better solution' for his time and place." ${ }^{36}$ Practitioners and policymakers may, therefore, learn from the experiences of other countries and take advantage of approaches that have proven effective in other contexts.

The standard taxonomy that prevails in comparative legal thinking envisions two principal procedural paradigms: the common law (or adversarial) model, and the civil law (or inquisitorial) model. ${ }^{37}$ In the comparative legal imagination, the adversarial model is rooted in "the medieval concept of "trial by combat,' where accuser (usually the victim) and accused would literally do battle to determine which party had truth on its side," ${ }^{38}$ while the inquisitorial model is linked to the procedure used during the Inquisition carried out

34 See Christopher L. Blakesley, Terrorism, Drugs, International Law, and the Protection of Human Liberty 33 (1992).

35 See Hafetz, supra note 24.

36 Konrad Zweigert \& Hein Kotz, An Introduction to Comparative Law 15 (Tony Weir trans., 3d rev. ed. 1998).

37 See, e.g., Mar Jimeno-Bulnes, American Criminal Procedure in a European Context, 21 Cardozo J. InT'L \& Comp. L. 409, 410 (2013).

38 Erik Luna, A Place for Comparative Criminal Procedure, 42 BRANDEIS L.J. 277, 295 (2004). 
by institutions within the Catholic Church starting in the twelfth century. ${ }^{39}$ Professor Mirjan Damaška notes that this "well-trodden path" in comparative legal analysis dates back at least as far as the twelfth century to differentiate between "a process that required the impetus of a private complainant to get under way (processus per accationem) from a process that could be launched in his absence (processus per inquisitionem). ${ }^{\prime 40}$ Today, the distinction is used to differentiate a common law model, "centered on adjudication, beginning its historical development with the conquest of England by the Normans," 41 from a civil law model, centered around the activity of a judge and "grounded in the traditions of Roman law." 42 This comparative legal taxonomy has even been used by the US Supreme Court:

What makes a system adversarial rather than inquisitorial is not the presence of counsel, much less the presence of counsel where the defendant has not requested it; but rather, the presence of a judge who does not (as an inquisitor does) conduct the factual and legal investigation himself, but instead decides on the basis of facts and arguments pro and con adduced by the parties. In the inquisitorial criminal process of the civil law, the defendant ordinarily has counsel; and in the adversarial criminal process of the common law, he sometimes does not. Our system of justice is, and has always been, an inquisitorial one at the investigatory stage (even the grand jury is an inquisitorial body), and no other disposition is conceivable. ${ }^{43}$

As a general matter, the civil law model of criminal procedure that prevails across much of the world adopts a procedural approach that "sees the determination of the entire truth of a case - viewed as an objective, almost omniscient understanding of the events in question - as the polestar of the criminal process, placing great importance on nonpartisan investigation prior to trial." Rather than viewing the process as a contest or a dispute, adjudication in the civil law model "is structured as an official inquiry," 44 in order to "guarantee that factually innocent individuals are not brought to trial." ${ }^{45}$ In such systems, the investigation is generally "led by a judicial officer, an examining magis-

39 In re Oliver, 333 U.S. 257, 271, 68 S. Ct. 499, 506, 92 L. Ed. 682 (1948) ("The criminal procedure of the civil law countries long resembled that of the Inquisition in that the preliminary examination of the accused, the questioning of witnesses, and the trial of the accused were conducted in secret").

40 Mirjan R. DamašKa, The Faces of Justice and State Authority: A Comparative Approach to the Legal Process 3 (1986).

41 See Jimeno-Bulnes, supra note 37, at 410.

$42 \quad I d$.

43 McNeil v. Wisconsin, 501 U.S. 171, 181, 111 S. Ct. 2204, 2210, 115 L. Ed. 2d 158 (1991).

44 See DAMAŠKA, supra note 40 , at 3.

45 See Luna, supra note 38, at 296-298. 
trate, who gathers information with the cooperation of law enforcement and the defendant." ${ }^{46}$ The entire process is "characterized by an active, centralized (state or judicial) enquiry, rather than a party-led process." 47

Common law or adversarial modes, in contrast, employ an adversarial (or accusatorial) approach that "pits the state-qua-public prosecutor against the defendant (the victim having been removed as a party), with each side presenting testimonial, documentary, or physical evidence to be judged by a neutral decision maker." In this model, the investigation of crime and the gathering of evidence are carried out by police or other law enforcement, without the involvement of the judiciary, and "evidence presented by one party is open to challenge by the other through vigorous cross-examination, where witnesses can be probed for bias, sensory limitations, defective memories, and so on." 48

With regard to detention, the legal literature routinely implies that one effect of the civil law or inquisitorial model's method is longer pretrial detention than one sees in common law or adversarial models. ${ }^{49}$ As an example, it has been asserted that a "notable feature of the French criminal justice system is the length of time a suspect can be held while this investigation takes place." 50 While in-depth studies call such assertions into question, ${ }^{51}$ the orthodoxy

46 Id.

47 Jacqueline S. Hodgson, The Metamorphosis of Criminal Justice: A Comparative Account 7 (2020).

48 See Luna, supra note 38, at 295-296.

49 Thomas Y. Davies, What Did the Framers Know, and When Did They Know It? Fictional Originalism in Crawford v. Washington, 71 BrooK. L. Rev. 105, 132-133 (2005):

However, that treatment ignored an important difference between Marian procedure and civil law inquisitorial procedure: a Marian examination of the arrestee and deposition of a witness was taken only after a named and potentially accountable accuser had made an arrest on the basis of a sworn accusation that a crime had been committed "in fact"; in contrast, because inquisitorial procedure did not require an accusation of crime in fact, it was perceived to allow officials to use detentions and interrogations abusively to "fish" for evidence that could be used to charge a crime.

See also Jonathan L. Hafetz, Pretrial Detention, Human Rights, and Judicial Reform in Latin America, 26 Fordham InT'L L.J. 1754, 1756 (2003).

50 Renée Lettow Lerner, The Intersection of Two Systems: An American on Trial for an American Murder in the French Cour d'Assises, 2001 U. ILL. L. Rev. 791, 804 (2001).

51 Martin Schönteich, Global Pretrial Detention Use: A Cross-National ANALYSIS, p. 162, https://academicworks.cuny.edu/cgi/viewcontent.cgi?article=3923\& context $=$ gc etds:

The hypothesis that, compared to civil law countries, common law countries have lower pretrial detention rates was not supported by the analysis. Rather, the analysis found that common law countries have significantly higher pretrial 
maintains that civil law systems more openly embrace pretrial detention ${ }^{52}$ as part of the investigative process. ${ }^{53}$ This comports with the basic philosophy of the civil law model, which emphasizes fact-finding during the pretrial phase and "places a great deal of trust, power, and responsibility" in investigating authorities. ${ }^{54}$ This stands in contrast to common law, which has historically emphasized due process, the protection of liberty, an expeditious judicial inquiry into the validity of detention, and a speedy trial of persons detained while awaiting trial. ${ }^{55}$

These are descriptions of different legal models as they exist in theory. But the ethereal forces of the legal cosmos are unruly, and far too dynamic to be contained by such academic orthodoxies. Laws change with the evolution of ideas and the vicissitudes of circumstances created in a world created beyond the pages of textbooks. Thus, it is no wonder that many commentators today stress that the labels applied to these procedural models are not entirely accurate and that no country truly stands as an avatar representing the purity of any one model. Moreover, this taxonomy has a Eurocentric aspect that tends to omit other legal traditions, such as the Islamic legal tradition and others. ${ }^{56}$ Nevertheless, even acknowledging the inherent incompleteness and limits of this comparativist mythos, such models retain some value "in conveying the roots of a legal system, its organizing principles and values, and so the kinds

detention rates than civil and mixed law countries, the latter two of which were not significantly different from each other. The hypothesis was based on the fact that in civil law regimes appeals may be taken both on the facts of a case and the law, and the appeal courts can open the record to receive new evidence. During such appeal processes defendants continue to be classified as remandees or pretrial detainees, often described as prisoners without a final sentence. The excessive duration of pretrial detention in civil law countries has also been commented on by van Caenegem (1999). By contrast, in common law countries appeals are relatively rare and prisoners are no longer classified as pretrial detainees once a guilty verdict has been made.

52 Louis M. Natali, Jr., Redrafting the Due Process Model: The Preventive Detention Blueprint, 62 Temp. L. Rev. 1225, 1230 (1989).

53 See Hodgson, supra note 47, at 245 (noting "[t]he historic role of the prosecutor as supervisor and guarantor of the detention process in the Netherlands and France").

54 Id. at 7.

55 Neil Douglas McFeeley, The Historical Development of Habeas Corpus, $30 \mathrm{Sw}$ L.J. 585, 589 (1976), https://scholar.smu.edu/smulr/vol30/iss3/4.

56 See DAMAŠKA, supra note 40, at 5 ("In short, the typology becomes cumbersome and difficult to employ as an instrument of analysis. It is of very limited use in providing comparativist orientation beyond justice systems in the West"). See also Hodgson, supra note 47, at 5 ("They neither describe nor are reflected in the criminal procedure of any single jurisdiction"). 
of considerations that might govern reform in order to maintain some degree of internal coherence." ${ }^{57}$

This book compares the counterterrorism regimes of three countries, each with a different legal tradition: the United States, the United Kingdom, and France. This exploration necessarily requires a foray into comparative law and an analysis of different legal models. Such a comparison presents opportunities for comparative legal analysis on a number of levels by permitting comparativists of critical capacity to observe the way in which these contrasting legal regimes fulfill the social needs or interests of each jurisdiction, and the way diverse legal traditions have adapted to address an evolving, yet shared problem. It further permits us to test the praesumptio similitudinis - a central methodological premise of comparative law that maintains that, in the approach different legal systems take to address a shared problem, those systems tend to develop functionally equivalent institutions that produce similar practical results. ${ }^{58}$

This comparison also permits us to evaluate trends in the divergence or convergence of legal systems, taking into account the legal models discussed above. Comparative lawyers have debated the issue of convergence and/or divergence since the rise of the discipline in the $1950 \mathrm{~s},{ }^{59}$ with some authors taking rather strident positions against the possibility of convergence (especially among legal systems thought to be too fundamentally different). ${ }^{60}$ The countries compared in this book provide apt subjects for this analysis due to their traditional juridical dissimilarity. The United States and the United Kingdom are generally considered archetypes of common law, while France is regarded as the avatar of the civil law model. Moreover, from a policy and legal perspective, the way France and the United Kingdom have chosen to deal with terrorism and the detention of terrorist suspects marks a point of distinction from the US approach. Kenneth Roth remarks that "among liberal democracies, the United Kingdom and France are arguably the most aggressive in granting the state latitude in detaining terrorist suspects." ${ }^{\prime 1}$ As such, one would expect that these countries would sit on opposite sides of a procedural divide, with the common law countries sharing common procedural traits

\footnotetext{
57 Hodgson, supra note 47.

58 See Ralf Michaels, in Oxford Handbook of Comparative Law 339-382 (Mathias Reimann \& Reinhard Zimmermann eds., 2006).

59 See Bruno de Witte, The Convergence Debate, 3 MaAstricht J. Eur. \& Comp. L. 105 (1996).

${ }^{60}$ Pierre Legrand, European Legal Systems Are Not Converging, 45(1) InTERNATIONAL AND COMPARATIVE LAW QuARTERLY 52 (1996).

${ }_{61}$ See Kenneth Roth, After Guantanamo: The Case Against Preventive Detention, Foreign AfFaIRs, May/June 2008.
} 
that are dissimilar from their civil law corollaries. As this book demonstrates, however, this is not necessarily true with regard to investigative detentionespecially in matters of counterterrorism. A comparative analysis of these legal systems, therefore, presents an opportunity for useful exploration of juridically heterogeneous legal systems, and one which serves to further challenge our understanding of existing comparative legal models.

\section{SUMMARY OF CHAPTERS}

The subject of this book is complex and requires a study of domestic law, international law, and comparative law. Chapter 2 highlights the international legal rules governing investigative detention, with a focus on international human rights law. Chapter 3 discusses the United States, highlighting its doctrinal and jurisprudential aversion to investigative detention, but also underscoring ways in which that aversion can be overcome in exceptional cases. Chapter 4 focuses on the United Kingdom and its particularly robust investigative detention regime. Chapter 5 details the French approach to counterterrorism and investigative detention, elucidating the unique approach of its legal tradition. Each chapter begins by detailing the experience a given country has had with terrorism and its legislative response to the threat. It then analyzes the general nature of the criminal justice system of that country, how that country's criminal law defines terrorism, and the country's law of detention-including any provisions for investigative detention in standard criminal matters. Thereafter, each chapter examines counterterrorism legislation in force and how that legislation augments the ordinary criminal law regime in cases of terrorism. Through an analysis of each country's domestic criminal procedure, this book will permit a reevaluation of where each country is situated on the comparative-legal continuum in relation to its counterparts. This book will also invite the reader to consider what lessons - cautionary or otherwise - can be gleaned from the experiences of other countries, and how a comparative legal approach can inform broader national security decision-making. It is also hoped that readers from divergent jurisdictions will find the analysis illuminates new aspects of their own law, and enhances their understanding of the familiar. As my friend, colleague, and mentor Professor Christopher L. Blakesley notes, "[w]orks of comparativists and others from diverse systems may reshape our prism, providing a chance to see different refractions, a fuller spectrum of possibilities, producing a deeper appreciation of one's own law and that of other systems."

62 Christopher L. Blakesley, Law, Language, Crime, and Culture: The Value and Risks of Comparative Law, 49 CRIM. L. Bull. 438, 459 (2013). 
It is with that observation in mind that this book embarks on its exploration of this fascinating and important subject. 